\title{
Three Layers of Metaphors in Ross Macdonald's Black Money
}

\section{ABSTRACT}

In his early career, Kenneth Millar, better known as Ross Macdonald, emulated the style of Dashiell Hammett and Raymond Chandler. By the 1960s he had established himself as a distinct voice in the hardboiled genre. In his Lew Archer series, he conveys the complexity of his characters and settings primarily by the use of metaphors. In his 1966 novel Black Money the device performs three functions. In the case of minor characters, the author uses metaphors to comment on Californian society. Concurrently, metaphors describing major characters allow him to develop their dramatic arcs, whereas the recurring elements of the leitmotif serve to demonstrate the narrating detective's growing concerns with the ongoing investigation. Arguably, it was Macdonald's use of metaphors that helped define his unique voice.

Keywords: Ross Macdonald, Lew Archer, hardboiled fiction, metaphor, blending. 


\section{BLACK MONEY}

Ross Macdonald inherited the hardboiled tradition from his predecessors Dashiell Hammett and Raymond Chandler. His novels maintained their bleak realism, sense of nostalgia and metaphor-heavy style. Still, they proved an intellectual reconceptualization of the genre. For example, critics have found Macdonald's novels to be thematic reworkings of The Waste Land (1922), The Great Gatsby (1925), as well as the Theban Plays (Nolan 122). His interest in psychology likewise influenced his treatment of crime. Being a psychoanalysis enthusiast, Macdonald wrote, "[Freud] made myth into psychiatry and I've been trying to turn it back into myth again in my own small way" (qtd. in Knapp 74). Indeed, the conflict of his later novels is structured primarily around psychological tensions that often afflict a family. His narrating detective, Lew Archer, is certainly "less of a tough guy than Sam Spade or Philip Marlowe," acting more as an analyst than the traditional fist-swinging "private eye" (Porter 108). Archer is certainly competent in his psychological assessment of both fleeting acquaintances and primary characters. He communicates many of his appraisals by the use of metaphors. It is perhaps the application of this device that allowed Macdonald to "elevate" the hardboiled genre by creating a "democratic literature that could be liked on different levels by all sorts of readers" (Nolan 122).

To demonstrate the complexity of the descriptions I borrow terms from Lakoff and Johnson's Metaphors We Live By (2003). Consequently, the "target domain" will identify what "is constituted by the immediate subject matter," meaning the described domain (traditionally "tenor"); the "source domain" will identify the domain "in which important metaphorical reasoning takes place and that provides the source concepts used in that reasoning," or the domain used to describe the target (traditionally "vehicle") (Lakoff and Johnson 266). Finally, the term "mappings" will identify the "systematic correspondences across domains" (traditionally "common ground") (246). Some metaphors will be said to be using "blends" understood as "mental space $[\mathrm{s}]$ that imaginatively combine elements of at least two other mental spaces that are structured by our ordinary longterm conceptual system" (261). Finally, the term conceptual metaphor will be used only in references to the non-poetic metaphors "grounded in everyday experience" (273).

The discussed figurative descriptions of characters and setting function on three levels: societal, dramatic, and reflective. The cited examples will address these layers in Black Money (1966). Published in the latter part of Macdonald's career, the novel coincided with the Space Race, the Cold War, the Vietnam conflict, the youth counterculture movements and a significant 
power shift at the Hollywood studios. These societal changes function as a backdrop to the story that may be seen as a 1960 s reconceptualization of F. Scott Fitzgerald's The Great Gatsby (1925), a novel that Macdonald claimed to have read annually (Gale 24).

Upon Black Money's release, reviews were mixed, with critics such as Sale Roger both hailing Macdonald as a novelist of "stunning psychodrama" and calling Black Money an innovative "failure" (Skinner 63). The story follows Lew Archer's investigation into the identity of Francis Martel. Martel, much like Jay Gatsby, has accumulated wealth by mysterious means. Archer learns about his fabricated identities, "regressing from a cultured French aristocrat to a Panamanian peasant" (Bruccoli and Layman 307). Eventually, Archer discovers that his employer has hired him to win back his ex-fiancée Virginia "Ginny" Fablon. Attracted to Martel's affluence, the beautiful Virginia is a character reminiscent of Daisy Buchanan. The woman's relationship with Martel turns out to be a triangle that includes her would-be mentor, professor Tappinger. By the end of the novel, the desperate academic kills both of Ginny's parents, as well as Martel before committing suicide.

\section{Level One: Societal Metaphors}

During the investigation, Lew Archer encounters various minor characters. Customarily, he assesses their integrity based on their appearances, surroundings, and behaviour. The observations are telling of their psychological states but more importantly serve as a commentary on Californian society. These societal metaphors can be found, amongst others, in Archer's description of a lifeguard.

The narrating detective encounters the athletic man at a sports club. Its mostly rich and elderly members occupy the locale pool deck. The lifeguard, it seems, is there primarily for their viewing pleasure. Archer observes:

His smooth simple face was complicated by a certain wildness of the eye. His blond head had not been able to resist the bleach bottle. .. He reminded me of the dumb blondes who had cluttered up the California landscape when I was his age. Now a lot of them were boys. . . The trouble was that there were thousands of him, neo-primitives who didn't seem to belong in the modern world. But it came to me with a jolt that maybe they were better adapted to it than I was. They could live like happy savages on the beach while computers and computer-jockeys did most of the work and made all the decisions. (Macdonald) 
Here, Archer compares the lifeguard to both a "dumb blonde" (metaphor one) and a "neo-primitive" (metaphor two). In the second metaphor, the source domain functions as a blend of the "modern man" and "the savage." Both terms propose mutually exclusive features. The mapping must be selective, favouring those which compliment the "dumb-blonde" domain from the previous metaphor. The "neo-primitive" blend is, therefore, primarily "savage" and secondarily "modern." If, on the contrary, the blend named "paleo-sophisticates" was produced, then the features' precedence would be reversed. As it stands, the complex metaphor proposes an image of a blonde and pedicured-neanderthal. The inconsistency is that although being the product of a natural selection, the new cave-man is inherently detached from the wilderness. He is likely incapable of sustaining himself in the wild. Instead, he is, as the "dumb-blonde" domain proposes, a "vain," "ignorant," and "effeminate" consumer. Paradoxically, he is more adept at surviving in the modern world than Archer, who implicitly encompasses the contrasting characteristics of "knowledge," "culture," and "dexterity." As such, he is less likely to be reliant on the consumeristic regime.

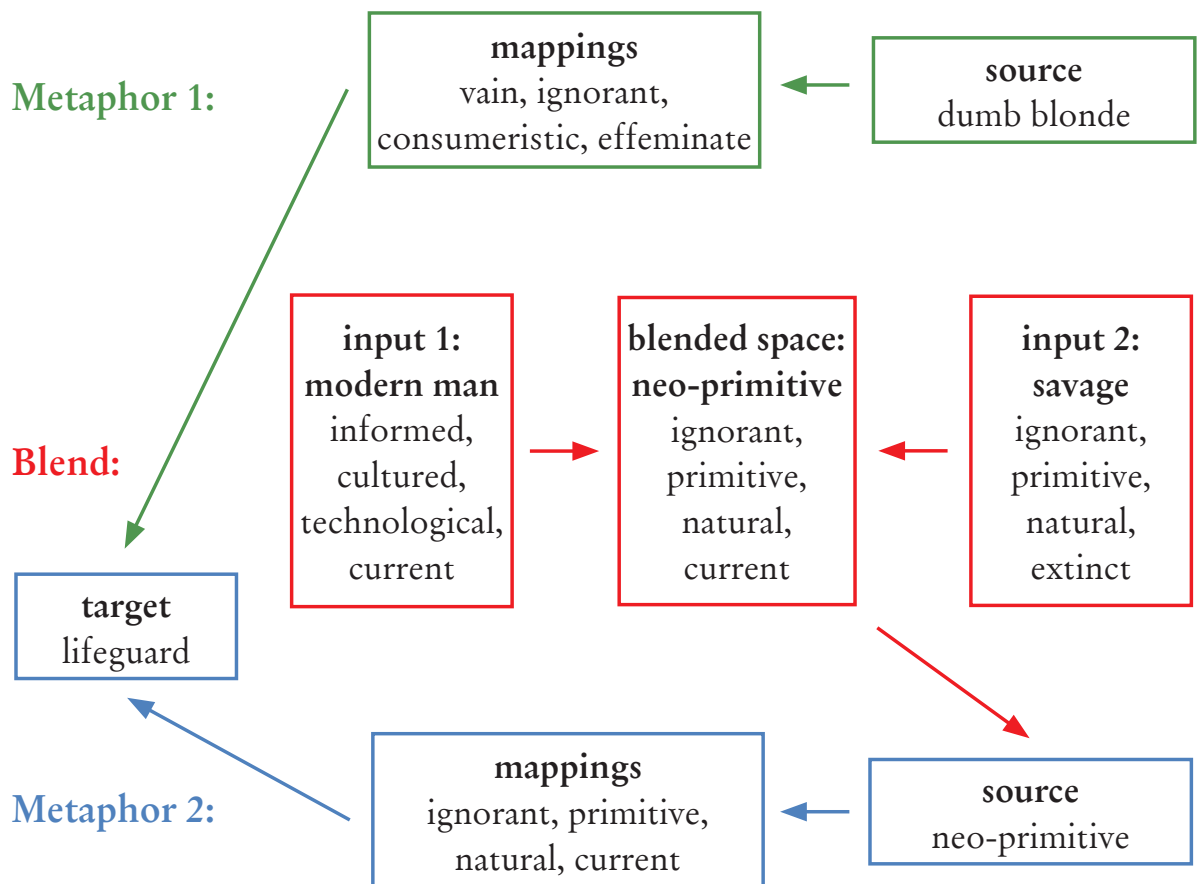

Fig. 1. The metaphors and blend describing the lifeguard as a neoprimitive. 
The mention of the "computer-jockey" calls attention to Macdonald's perspective on the United States' scientific progress during the Space Age. Modern man's evolution, Archer seems to suggest, is not facilitated by the booming technologies. On the contrary, computers aid his intellectual demise. The notion of the "happy savage" seems like a reference to the maxim that "ignorance is bliss." But the threat of the "computer-jockey" making "all the decisions," implies that the lifeguard's willing self-degradation is not reactionary but engineered. At best, he is routed for consensual enslavement. Archer fears that the generation of people invested primarily in their physical appearance will make for an easily manipulated herd.

In a later passage, Archer draws out his speculations when comparing a shopping centre with the recently visited Montevista State College: "We drove to the Plaza in ticking silence. It was a large new shopping centre, like a campus with asphalt instead of lawns where nothing could be learned" (Macdonald). Submitting the "asphalt-lawn" relation as the defining contrast between a mall and an institution of higher learning, Archer proposes that the difference is cosmetic. Both establishments cater to the same demand for goods and services. Education is regarded as a product. The lifeguard's connection to the above description lies in his admission of being enrolled at Montevista. His portrait of unintelligence is Archer's final argument that education's potential new line is to foster neo-primitive consumers and not intellectuals.

\section{Level Two: Dramatic Metaphors}

Archer's assessments are impressive even when demonstrated during onetime encounters such as the one with a sports club lifeguard. However, his prowess is more evident in the interactions with characters he continuously engages over the course of the entire story. His descriptions reveal the motivations of a given character's behaviour. The descriptions of the novel's femme fatale, Virginia "Ginny" Fablon, effectively demonstrate Macdonald's second (dramatic) level of metaphors.

As mentioned, Ginny is a young socialite with a presumably bright future. However, her promising façade hides a history of abuse and secrets. In the years preceding the story, she had an affair with her then college professor, Tappinger. Her father forced her to abort the resulting pregnancy, causing an irreconcilable rift in their relationship. The discord ended with her father's murder at Tappinger's hands. This event marked Ginny's submission to the role of femme fatale. As the story opens, Ginny is engaged to Francis Martel, the man whom Archer was hired to investigate. Ginny sits in the car, while Martel threatens a minor character he caught 
taking pictures of them. Archer describes the girl: “though I couldn't see her eyes, she seemed to be looking back across the road at me. The lower part of her face was immobile as if she was afraid to react to the situation. It had the dead beauty of marble" (Macdonald, italics mine). Archer compares her face (target domain) to a marble statue (source domain), emphasizing the "dead" quality. Because the source domain maps connotations of Greco-Roman art, the target grants itself to an image of a dispassionate goddess. Archer's instinctual observation is that she is a beauty no longer impressed by admiration. Her "deadness" is emotional, though at this point in the story Archer assumes it to be the results of fear.

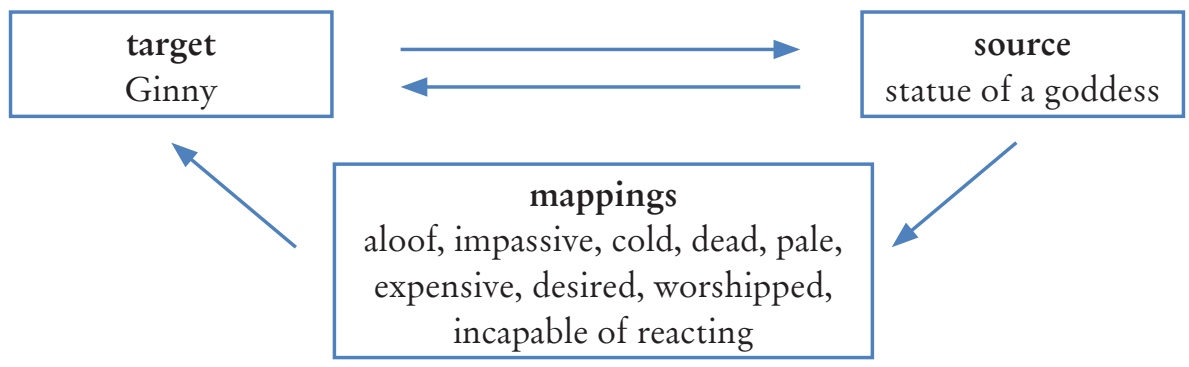

Fig. 2. Ginny as a statue metaphor.

The second time that Archer encounters Ginny is when visiting her fiancé's house. The detective intends to unmask Martel as a fraud. Ginny appears in the door dressed in a "grey suit, the kind women use for traveling. Her movements seemed shaky and her eyes a little dull, as if she had already traveled too far and too fast" (Macdonald). Then he adds, "perhaps it was the brilliant light shining down on her face, but its skin appeared greyish and grainy. She had the sort of beauty-shape of head, slant of cheekbone and chin, curve of mouth - that made these other things irrelevant" (Macdonald). The description of her greyish, grainy skin and beauty references the statue-metaphor. It reaffirms Archer's initial impressions of Ginny's aloof grandeur. Archer is still unaware of Ginny's past. Nevertheless, he capably assumes her remoteness to be a result of trauma rather than a pampered upbringing. He also notes the effect that her "sort of beauty" might have on her beholders. The fact that it renders her remaining qualities "irrelevant," suggests that Archer recognizes that Ginny is prized primarily for her appearance.

Interestingly, the above metaphor (Ginny as a statue) builds on a conceptual metaphor. It is the metaphor of experience understood in terms of spatial progress, or more simply put "life [as] a journey" (Evans and Green 287). By noting that Ginny has "traveled too far and too fast" Archer is in fact referring to her life's journey, despite her being dressed in a grey "traveling 
suit." He uses her apparel as a point of departure for the life-as-a-journey metaphor. Thus his metaphor is compound. Life-as-a-journey serves as input one, that blends with Ginny (input two) providing the idea of "Ginny's journey." Next, the reader compares the "blend" with an augmentation of "life as a journey," in which the mode of travel is characterized by "reckless driving." The mappings reveal Archer's presupposition that Ginny's past has been traumatizing. The initial metaphor (source domain) is provided with the attributes of "speeding" and "overshooting." Thus the mappings of "recklessness," "missed destination" and "neglect of hazards" are carried over to "Ginny's life journey" (target domain).

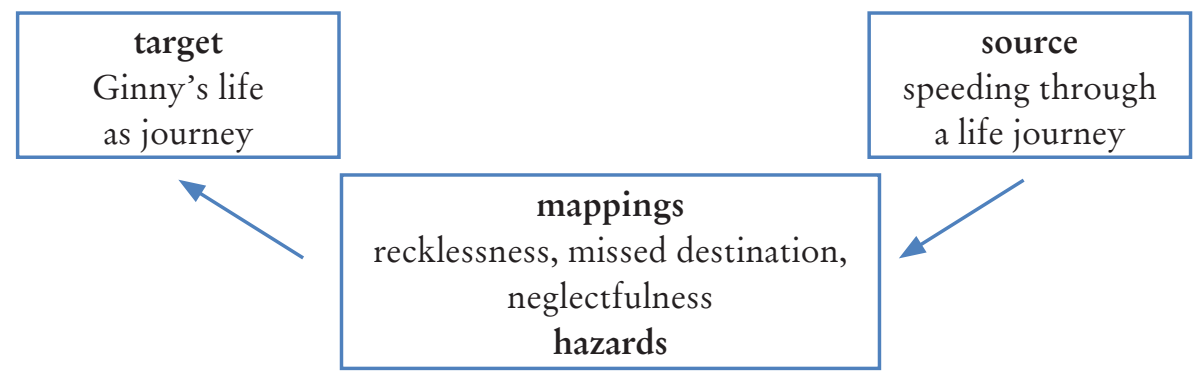

Fig. 3. Ginny’s life-as-a-journey metaphor.

After Martel's murder, Archer continues to reference the life-as-ajourney conceptual metaphor in regards to Ginny. First, he notes that "the shock of Martel's death had pushed her back toward childishness. Her voice sounded just a little like a sleep-talker's" (Macdonald). He retains the idea of spatial correlation (being pushed back) to stages of Ginny's development (childhood). Then, three pages later, he admits that the girl surprised him:

I reminded myself that she wasn't a girl, but a woman with a brief tragic marriage already behind her. And what sounded like a long tragic childhood. Her voice had changed perceptibly, almost as though she had skipped from youth to middle age. (Macdonald)

Again the "life-as-a-journey" metaphor serves as the basis upon which Archer layers meaning. He maps her life events onto the previous blend of "Ginny's life as a journey." Thus, her husband's tragic death serves as the culmination point that divides her "youth" from "middle age." The image appeals to the reader's familiarity with a conventional lifeline that may consist of youth, teenage years, young adulthood, middle age, etc. This concept serves as the domain that provides the contrast by emphasizing the irregularities of Ginny's timeline. The reader may note that several 
stages of development might have been overtaken by what Archer calls a "long and tragic childhood." In other words, his point may be distilled to the notion that traumatic experiences have forced Ginny to grow up too quickly, but he expresses the idea by evoking an image of a traveler traversing their tailored-by-tragedy timeline.

Ginny's subsequent characterization occurs soon after the story's climax. As Archer drives the woman home she asks, "why do real things always have to be ugly and horrible?' She was feeling the pain now, I thought, the cruel pain of coming home widowed after a three-day marriage" (Macdonald). The expression of Ginny's disenchantment with childhood fantasies resonates with the reckless life-journey metaphor. However, the following description introduces a new metaphor to the same image:

The energy that had conceived the dream, and forced it briefly into reality, had all run out now. Even the girl beside me was lax as a doll, as if a part of her had died with the dreamer. She didn't speak again until we reached her mother's house. (Macdonald)

In this excerpt, Archer refers to Francis Martel. His version of the American Dream entailed a luxuriant life with Ginny. The metaphor once again is multileveled. Archer uses a simile to create a parallel between Ginny (target) and a lax doll (source). Her affinity with an inanimate figurine calls attention not only to her emotional depletion but more importantly to the idea that Ginny was merely a component of Martel's dream. She was objectified even by the man who claimed to have loved her.

However, Ginny's character arc does not end with her husband's death. Her character is further revealed in the final confrontation with her ex-lover, Professor Tappinger. After Archer reveals that the man is responsible for the murders of Ginny's father, mother, and husband, Tappinger commits suicide. The detective enters the room to find Ginny lying on the floor "face to face" with the dead professor. He describes seeing

their profiles interlocking like complementary shapes cut from a single piece of metal. She lay there with him, silent and unmoving, until the noise of the sirens was heard along the road. Then she got up and washed her face and composed herself. (Macdonald)

In this final comparison, the source of "interlocking metal shapes" maps "complementation" and "close resemblance" onto the target of their "profiles." The same idea was planted in Archer's earlier observation that, "they were very nearly the same height and weight, and they had the same fine regular features. They could have been brother and sister. I wished they had been" (Macdonald). Ginny's comparison with the dead lover might 
symbolize her lost potential to love. More interestingly, her expression of tenderness for the killer suggests her acquiescence to his actions. The dialogue exchange that precedes Tappinger's suicide, reveals the lovers' plan was "for [Ginny] to marry Peter [Archer's employer]. [Ginny] was simply to divorce him and get a settlement, so that Tappinger and [she] could go away" (Macdonald). The implication is that the professor committed the murders out of his passion for Ginny. Such an idea, Archer implies, seemed to have flattered the woman.

Importantly, in Tappinger's death scene, the two lovers are "complementary," not identical. The mirror image of their facing profiles epitomizes the thematic pursuit of an ideal self. Conceivably, both Ginny and Tappinger saw their improved reflections in each other. She saw him as a completion of her knowledge and culture; he saw her as a source of his depleting youth. Ultimately, both partners seemed to be in love, not with the other but with the idea of their idealized selves. The relationship was a form of narcissism, and in such a context their similitude, Archer thinks, rendered Ginny and Tappinger the only viable match.

Having witnessed several failed relationships (the Hendricks, the Tappingers, the Fablons, the Martels) Archer blames objectification of women as the cause of these breakdowns. He surmises: "I thought that Ginny and Kitty ... had quite a lot in common after all. Neither one had quite survived the accident of beauty. It had made them into things, zombies in a dead desert world, as painful to contemplate as meaningless crucifixions" (Macdonald). The description consists of several metaphors. The first one uses the source of "accident" to map features of "fatal consequences" onto the target of "beauty." The idea is that the females' attractiveness results in their metaphoric death. Next, Archer maps qualities of "mindless presence" from the source of "zombies" on to the target of "women." By doing so, he delineates the consequences of the "death by beauty" metaphor to be a feeling of purposeless existence. $\mathrm{He}$ then provides a third metaphor comparing the female's perception of the world to a dead desert. They become "dead" to the world, while the world becomes dead to them. Being objectified, Archer suggests, deprives the likes of Ginny and Kitty of their humanity. They become femmes fatales in reaction to the males' superficial perception of them.

\section{Level Three: Thematic Metaphors}

Black Money establishes the theme of "man versus nature" in its opening passage. Archer enters an exclusive sports club noting a "fifty-meter pool which was enclosed on three sides by cabanas. On the fourth 
side, the sea gleamed through a ten-foot wire fence like a blue fish alive in a net" (Macdonald). The composition of the club's space might be betraying its members' will to bridle nature. However, in the novel, such descriptions serve to delineate the narrator's changing interpretation of the environment, and are less telling of other characters. Manifestations of the wind coincide with Archer's investigation. This leitmotif is used to externalize the narrator's condition and as such constitutes the third (thematic) layer of the discussed metaphors.

The first mention of the wind precedes Archer's initial encounter with Martel. His anxiety comes through in the description. "Approaching the Tennis Club, I could feel a cool wind from the ocean on my face. The flag on top of the main building was whipping ... The afternoon wind had driven away most of the sunbathers"(Macdonald). At this point, it is not apparent that the wind will act as a personified agent, though such an idea is suggested by its "driving away of sunbathers." The element's role is to evoke an atmosphere of disquiet.

The personification of nature becomes evident in the subsequent description. Approaching the place where "Fablon [Ginny's father] had taken his final swim," Archer perceives the location's foreboding mood. "An unsteady wind carrying a gritty taste of desert was blowing down from the direction of the mountains. The eucalyptus trees swayed and bowed and waved in the gusts like long-haired madwomen racked by impulse" (Macdonald). The "gritty taste of desert" is likely a reference to the Santa Ana winds that descend to the Pacific Coast "from the inland desert region" ("Santa Ana Wind"). Interestingly the so-called "devil winds," are believed to affect the inhabitants' moods (see Stephenson 39; Medina). This seems to be Archer's case. As the complex metaphor proposes, he envisions the wind as a supernatural presence. The target "eucalyptus" moving like the source "madwomen," maps the idea of "possession" on to the trees. Because the wind acts as the trees" animator, the metaphor compares it, the target, to the source of "possessor." Having established the wind as an evil spirit, Archer relates,

as I drove along the windswept boulevard, my mind was so fixed on Harry that when I saw the Cadillac parked at the curb I thought I was dreaming... I looked around me. It was a lonely place, especially at this time, with a wind blowing. (Macdonald)

Archer's seemingly altered consciousness (dreaming) might be a sign of a tampered perception. He seems to sense the wind's interference with his uncovering of the truth.

Archer succeeds in overcoming the wind only temporarily. While questioning a minor character, Mrs Hendricks, he is revisited by a sense 
of foreboding. The woman is the wife of a man that Archer is trying to locate. She is good-looking and seemingly interested in the detective. Archer observes as "she shook her head. Her hair flared out like fire. The wind, momentarily louder than the music, was whining at the window" (Macdonald). The wind's accompanying of Mrs Hendricks's seductive measures underscores Archer's belief that the possessor has taken hold of the woman in an attempt to prevent him from learning about her husband's murder. Once he escapes the allurement, the wind resorts to more desperate means: "we drove along the boulevard. The rising wind buffeted the car. Out to sea, I could make out occasional whitecaps" (Macdonald). The wind, Archer feels, is trying to physically push him off the road.

After consulting the sports club photographer, Archer comes to the brink of an important discovery. The wind again assumes its violent form:

I ... drove back into the foothills. This was the direction the wind was coming from. It rushed down the canyons like a hot torrent and roared in the brush around the Bagshaw house. I had to brace myself against it when I got out of the car. (Macdonald)

Archer elaborates the possessor-metaphor, while his word choices"rushed down," "roared"-accentuate the impression of an attack.

Contrarily, the novel's midpoint is marked by the wind's absence. Having retired for the night, Archer notices that "the wind died just before dawn. I heard the quiet and woke up wondering what was missing" (Macdonald). The wind's pervasiveness became an expected part of Archer's environment. Its sudden withdrawal causes him to feel discomfort. This correlates to the plot's tension. Archer soon acquires evidence that proves his suspect is lying. What follows is an intensified barrage: "the wind was making so much noise I didn't hear him come up behind me" (Macdonald).

Since Macdonald's detective follows in the tradition of the hardboiled loner, the wind metaphors provide the only access to his veiled fears. Black Money's Santa Ana winds do more than just evoke a mood. They externalize the guarded detective's psychological state. Moreover, they supplement the novel's social commentary; nature seems to be acting in response to California's inhabitants' efforts to bridle its forces. Macdonald continued to develop environmentalist themes in his subsequent novels, notably in The Underground Man (1971) and Sleeping Beauty (1973) (see Gale 255, 291). Nevertheless, it was Black Money that solidified his unique use of metaphors, garnering him both critical and popular acclaim (Bruccoli and Layman 278). 


\section{Works Cited}

Bruccoli, Matthew Joseph, and Richard Layman. Hardboiled Mystery Writers: Raymond Chandler, Dashiell Hammett, Ross Macdonald: A Literary Reference. New York: Carroll and Graf, 2002. Print.

Evans, Vyvyan, and Melanie Green. Cognitive Linguistics: An Introduction. Edinburgh: U of Edinburgh P, 2006. Print.

Gale, L. Robert. A Ross Macdonald Companion. Westport: Greenwood, 2002. Print.

Knapp, John. "Ross Macdonald, Family Systems Detective." Clues: A Journal of Detection 24 (2006): 73-88. Print.

Lakoff, George, and Mark Johnson. Metaphors We Live By. Chicago: U of Chicago P, 2011. Print.

Macdonald, Ross. Black Money. New York: Knopf, 1966. ePUB.

Medina, Jennifer. "Santa Ana Winds, Unusually Strong, Rattle More Than Nerves in California." Nytimes.com. The New York Times 2 Dec. 2011. Web. 1 Jul. 2019.

Nolan, Tom. Ross Macdonald: A Biography. New York: Scribner, 1999. Print.

Porter, Dennis. "The Private Eye." The Cambridge Companion to Crime Fiction. Ed. Martin Priestman. Cambridge: U of Cambridge P, 2003. 95-114. Print.

"Santa Ana Wind." W1.weather.gov. NOAA's National Weather Service Glossary. Web. 1 Jul. 2019.

Skinner, Robert S. The Hard-Boiled Explicator: A Guide to the Study of Dashiell Hammet, Raymond Chandler and Ross Macdonald. London: Scarecrow, 1985. Print.

Stephenson, Terry E. “The Santa Ana Wind.” California Folklore Quarterly 2.1 (1943): 35-40. Print.

\section{Lech Zdunkiewicz, currently enrolled in the $\mathrm{PhD}$} program at the University of Wrocław, specializes in modern American literature. His MA thesis for the University of Wrocław was a finalist of the MA Thesis Award of the Polish Association of American Studies for 2017. His current research concerns the antihero in Patricia Highsmith's Ripliad. Since 2008 he has been involved in various independent and studio film productions.

\section{mr.zdunkiewicz@gmail.com}

